\title{
PENGEMBANGAN INSTRUMEN LITERASI DIGITAL SEKOLAH SISWA DAN GURU
}

\author{
Asyti Febliza*, Oktariani
}

Program Studi Pendidikan Kimia, Fakultas Keguruan dan Ilmu Pendidikan Universitas Islam Riau

\begin{tabular}{l}
\hline \multicolumn{1}{c}{ Informasi Artikel } \\
\hline Sejarah Artikel: \\
Diterima; 26-12-2019 \\
Disetujui; 20-01-2020 \\
Dipublikasikan; 27-01-2020 \\
\hline Keywords: \\
Digital literacy, Instrument \\
developing, \\
Validity, \\
Reliability \\
\hline
\end{tabular}

\section{A b s t r a k}

Penelitian ini bertujuan untuk mengembangkan instrumen literasi digital sekolah, guru dan siswa yang berfungsiuntuk mengukur sejauh mana tingkat literasi digital sekolah, guru, dan siswa. Tidak mungkin suatu sekolah dapat mengikuti perkembangan IPTEK jika potensi sekolah tidak memadai dan sumber daya manusianya belum siap. Oleh karena itu, pengembangan instrument literasi digital perlu dibuat agar dapat mengidentifikasi tingkat kesiapan sekolah, guru dan siswa dalam menghadapi era digital di revolusi industri 4.0. Subjek penelitian yaitu 90 responden yang terdiri dari 30 orang guru dan 60 orang siswa di SMA Negeri 14 Pekanbaru. Angket yang telah dibuat terlebih dahulu divalidasi oleh 2 validator ahli, setelah dinyatakan valid oleh validator ahli selanjutnya angket dilakukan uji terbatas untuk menghitung tingkat validitas dan realiabilitas masing-masing item pertanyaan. Angket menggunakan skala likert dengan 3 kategori pilihan jawaban (sering, jarang, tidak pernah atau ada, sedang direncanakan, tidak, dsb). Berdasarkan hasil dan kesimpulan dapat ditarik kesimpulan yaitu: butir pertanyaan yang dapat dijadikan sebagai alat pengumpul data pada instrumen angket literasi digital sekolah yaitu sebanyak 23 butir pertanyaan, sedangkan butir pertanyaan yang dapat dijadikan sebagai alat pengumpul data pada instrumen angket literasi digital guru 52 butir pertanyaan dan instrumen angket literasi digital siswa sebanyak 31 butir pertanyaan. Berdasarkan kriteria reliabilitas, ketiga angket literasi digital menunjukkan kriteria reliabilitas tinggi dan sangat tinggi dengan tingkat reliabilitas lebih besar dari 0,684 .
A b s tract
This study aims to develop digital literacy instruments for schools, teachers and students whose function is to measure the extent of the digital literacy levels of schools, teachers, and students. It is not possible for a school to follow the development of science and technology if the school's potential is inadequate and its human resources are not ready. Therefore, the development of digital literacy instruments needs to be made in order to identify the level of readiness of schools, teachers and students in facing the digital era in the industrial revolution 4.0. Subjects of the study were 90 respondents consisting of 30 teachers and 60 students in SMA Negeri 14 Pekanbaru. The questionnaire that was made was first validated by 2 expert validators, after being declared valid by the expert validator, then the questionnaire was conducted a limited test to calculate the level of validity and reliability of each question item. The questionnaire uses a Likert scale with 3 categories of answer choices (often, rarely, never or there is, is being 
planned, no, etc.). Based on the results and conclusions, conclusions can be drawn, namely: the items that can be used as data collection tools on the school digital literacy questionnaire instrument are 23 questions, while the items that can be used as data collection tools on the teacher's digital literacy questionnaire are 52 items and instrument digital student literacy questionnaire as many as 31 questions. Based on the reliability criteria, the three digital literacy questionnaires show high and very high reliability criteria with a reliability level greater than 0.684 .

(C) 2020 Universitas Riau

\footnotetext{
*Alamat korespondensi:

e-mail: asytifebliza@edu.uir.ac.id

No. Hp : 081365321702
}

\section{PENDAHULUAN}

Perkembangan ilmu pengetahuan dan teknologi semakin pesat di abad ke-21. Budaya literasi merupakan prasyarat kecakapan hidup abad ke-21 yang harus dikembangkan melalui pendidikan yang terintegrasi mulai dari keluarga, sekolah dan masyarakat. Wilson \& Ph (2015) melakukan survey kepada 424 siswa kelas 10 dan 12 di daerah pedesaan Kanada mengenai aktivitas literasi digital dan menemukan bahwa frekuensi kegiatan penggunaan teknologi digital berpotensi meningkat baik di dalam ataupun diluar kelas. Selain itu, Shopova (2014) telah mengadakan survey kepada 60 orang mahasiswa tingkat pertama dan kedua dan menemukan bahwa sebagian besar mahasiswa yang masuk ke universitas memiliki keterampilan yang baik dalam menggunakan jejaring sosial, e-mail atau skype, surfing internet sebagai komunitas di dunia maya, namun pengetahuan dan kompetensi mahasiswa mengenai penggunaan teknologi untuk proses pembelajaran masih tergolong rendah.

Penelitian lainnya yang dilakukan oleh Asosiasi Penyelenggara Jasa Internet Indonesia (APJII) bersama Pusat Kajian Komunikasi (Puskakom) Universitas Indonesia menemukan bahwa jumlah pengguna internet di Indonesia mencapai 88,1 juta orang per awal 2015 (Kurnia, Santi, \& Astuti, 2017). Info lain yang dilansir oleh Wearesocial jumlah pengguna internet di indonesia pada Januari 2016 sampai Januari 2017 mengalami peningkatan sebesar 51\% dengan angka mencapai 132,7 juta pengguna. Sejak tahun 2016 Kementerian Pendidikan dan Kebudayaan menggiatkan Gerakan Literasi Nasional (GLN) sebagai implementasi dari Peraturan Menteri Pendidikan dan Kebudayaan Nomor 23 Tahun 2015 tentang Penumbuhan Budi Pekerti (Pendidikan \& Jakarta, 2017). Gerakan Literasi Nasional ini dilakukan untuk mengembangkan budaya literat digital.

Berdasarkan survey yang dilakukan oleh Keminfo bekerja sama dengan UNICEF pada anak dan remaja usia 10-19 (sebanyak 400 responden) yang tersebar di seluruh Indonesia dan mewakili wilayah perkotaan dan perdesaan, diperoleh informasi bahwa sekitar 79,5\% anak dan remaja adalah pengguna internet dan media digital. Hal ini mengakibatkan terjadinya transisi, dimana anak-anak dan remaja usia sekolah senang menggali informasi melalui internet dan media digital, menyukai pelajaran yang menarik yang dapat langsung digunakan dengan berbagai aplikasi yang tersedia dan cenderung menyukai dunia virtual. Era digital menuntut guru harus mampu mengikuti perkembangan IPTEK sehingga pembelajaran yang disajikan sesuai dengan perkembangan zaman. Namun, fenomena yang terjadi di lingkungan Pendidikan, guru masih lambat dalam mengejar lajunya tingkat modernisasi, banyak menggunakan produk 80-an, dan menggunakan sistem Pendidikan abad 20, hal ini menyebabkan terjadinya perbedaan secara radikal antara siswa dan guru (Wartomo, 2016).

Literasi digital merupakan kecakapan hidup (life skills) yang tidak hanya melibatkan kemampuan menggunakan perangkat teknologi, informasi, dan komunikasi, tetapi juga kemampuan bersosialisasi, kemampuan dalam pembelajaran, dan memiliki sikap, berpikir kritis, kreatif, serta inspiratif sebagai kompetensi digital. Penelitian mengenai literasi digital telah banyak dilakukan diantaranya: penelitian yang dilakukan oleh Jaringan Pegiat Literasi Digital (JaPeLiDi) melakukan pemetaan terhadap peta gerakan literasi digital di Indonesia dengan studi mencakup pelaku, ragam 
kegiatan, kelompok sasaran dan mitra. Temuan dalam penelitian yang menyangkut pelaku literasi digital yaitu: perguruan tinggi adalah pelaku utama atau motor dalam gerakan literasi digital perguruan tinggi $(56,14 \%)$ adalah pelaku utama yang disusul dengan pemerintah $(14,34 \%)$, komunitas $(13,52 \%)$, lembaga swadaya masyarakat (5,32\%), sekolah dan korporasi masing-masing sebesar 3,68\%. Dari aspek kegiatan, sosialisasi adalah kegiatan yang paling sering dilakukan yaitu dengan persentase sebesar $29,64 \%$, remaja dan pelajar $(29,55 \%)$ merupakan kelompok sasaran yang paling dominan yang menjadi jangkauan kegiatan literasi, dan mitra yang paling banyak dilibatkan adalah sekolah dengan persentase $32.07 \%$ (Kurnia et al., 2017). Berdasarkan temuan yang diperoleh oleh JaPeLiDi, terlihat bahwa pelaku literasi digital di sekolah hanya sebesar 3,68\%, hal ini menunjukkan masih rendahnya pelaku literasi digital di sekolah. Untuk meningkatkan tingkat literasi digital di sekolah perlu dilakukannya pendeteksian kesiapan sekolah, guru dan siswa dalam melaksanakan literasi digital. Dari aspek kelompok sasaran dan mitra yang dilibatkan dalam literasi sekolah yaitu pelajar dan sekolah dengan persentase berturut-turut sebesar 29,55\% dan 32,07\%. Jika dikaitkan dengan data dari segi pelaku literasi digital sekolah, barang tentu hal ini menjadi temuan tidak sinkronnya antara ketiga data tersebut. Oleh karena itu, penelitian ini bertujuan mengukur tingkat literasi dari sekolah, guru dan siswa sekaligus, agar diperoleh sinkronisasi data terhadap tingkat literasi sekolah.

UNESCO menunjukkan bahwa sekolah-sekolah di beberapa negara kekurangan perangkat ICT dan koneksi internet sekitar 90\% di Banglades, Kamboja, Kyrgizstan, Nepal, dan 50\% Indonesia.. UNESCO menunjukkan bahwa sekolah-sekolah di Indonesia 50\% masih belum memiliki perangkat ICT dan koneksi internet. Oleh karena itu, peneliti dalam hal ini mengkaji kesiapan sekolah dalam menggiatkan budaya literasi digital di sekolah.

Penelitian yang dilakukan oleh Kharisma mengenai digital literasi Guru SMA se-Kota Surabaya, diperoleh kemampuan literasi digital Guru SMA se-kota Surabaya dalam kategori tinggi (Herdhita Vidya, 2017). Tingkat literasi digital setiap guru berbeda-beda di setiap wilayah di Indonesia, Surabaya merupakan salah satu kota besar di Indonesia, sedangkan kota Pekanbaru merupakan kota kecil yang berada di pulau Sumatera. Sehingga tingkat literasi guru-guru SMA sekota Pekanbaru perlu diteliti.

A'yuni, (2015), mendeteksi bahwa tingkat literasi remaja usia sekolah (SMP dan SMA) di kota Surabaya berdasarkan aspek internet searching, hypertextual navigation, dan knowledge assembly kedalam kategori tinggi, sedangkan literasi digital pada aspek content evaluation masih tergolong rendah. Rendahnya tingkat content evaluation menunjukka siswa belum dapat memilah dan memilih konten yang tepat yang mendukung proses pembelajaran. Oleh karena itu, dalam meningkatkan tingkat literasi siswa diperlukan kerjasama berbagai pihak sekolah. Penelitian lain mengkaji hubungan yang signifikan antara literasi digital dengan self-directed learning dan e-resources (Akbar \& Anggaraeni, 2017; Nurjanah, Rusmana, \& Yanto, 2017). Jika tingkat literasi seorang peserta didik tinggi, maka tingkat kemandirian belajarnya dan keahlian dalam mengakses sumber elektronik pun akan meningkat. Oleh karena itu, penelitian ini dimaksudkan untuk meneliti sejauh mana tingkat literasi siswa.

Dari beberapa penelitian yang telah dilakukan oleh peneliti lain, terlihat bahwa penelitian yang akan dilakukan oleh peneliti memiliki beberapa keunggulan diantaranya: 1) mendeteksi tingkat literasi digital sekolah, guru, dan siswa secara sekaligus pada SMA Negeri se-kota Pekanbaru dengan sistem pengambilan sampel Clustering Sampling yaitu sekolah cluster tinggi, sedang dan rendah. Penelitian sebelumnya hanya meninjau tingkat literasi siswa saja, atau guru saja tanpa melihat apakah sarana dan prasarana sekolah mendukung terhadap budaya literasi. Dalam mengkaji keberhasilan literasi dalam dunia pendidikan harus mengkaji dari ketiga unsur sekolah tersebut yaitu sekolah, guru dan siswa, karena sinergi dari ketiganya akan mempermudah dalam membangun budaya literasi dalam dunia pendidikan. 2) instrumen pengujian literasi digital untuk sekolah, guru dan siswa akan validasi oleh ahli untuk mendapatkan kuesioner yang eligible. Dengan demikian, akan terdeteksi komunitas sekolah yang memiliki tingkat literasi digital established, Potential, dan Nonpotential. Hasil penelitian ini 
akan digunakan untuk merancang aplikasi digital untuk sekolah yang memiliki tingkat literasi digital established, sehingga proses pembelajaran yang dilakukan akan berbasis literasi digital untuk menghadapi tantangan kecakapan hidup di abad ke-21.

Penelitian ini bertujuan untuk mengembangkan instrumen literasi digital sekolah, guru dan siswa yang berfungsiuntuk mengukur sejauh mana tingkat literasi digital sekolah, guru, dan siswa. Tidak mungkin suatu sekolah dapat mengikuti perkembangan IPTEK jika potensi sekolah tidak memadai dan sumber daya manusianya belum siap. Oleh karena itu, pengembangan instrument literasi digital perlu dibuat agar dapat mengidentifikasi tingkat kesiapan sekolah, guru dan siswa dalam menghadapi era digital di revolusi industri 4.0.

\section{METODE PENELITIAN}

Model Plomp dikenal pula sebagai design research yang memiliki tahapan berupa preliminary research, prototyping phase, dan assessment phase dalam proses pengembangannya. Model penelitian ini dapat dimodifikasi menjadi beberapa tahapan yang meliputi (1) fase investigasi awal, (2) fase desain, (3) fase realisasi, (4) fase tes, evaluasi, dan revisi, dan (5) fase implementasi (Plomp, T., dan Nieveen, 2010). Subjek penelitian yaitu 90 responden yang terdiri dari 30 orang guru dan 60 orang siswa di SMA Negeri 14 Pekanbaru. Setiap guru mengisi dua jenis angket yaitu angket literasi digital sekolah dan angket literasi digital guru, sedangkan siswa hanya mengisi angket literasi digital siswa. Adapun prosedur penelitian dapat dilihat pada gambar 1.

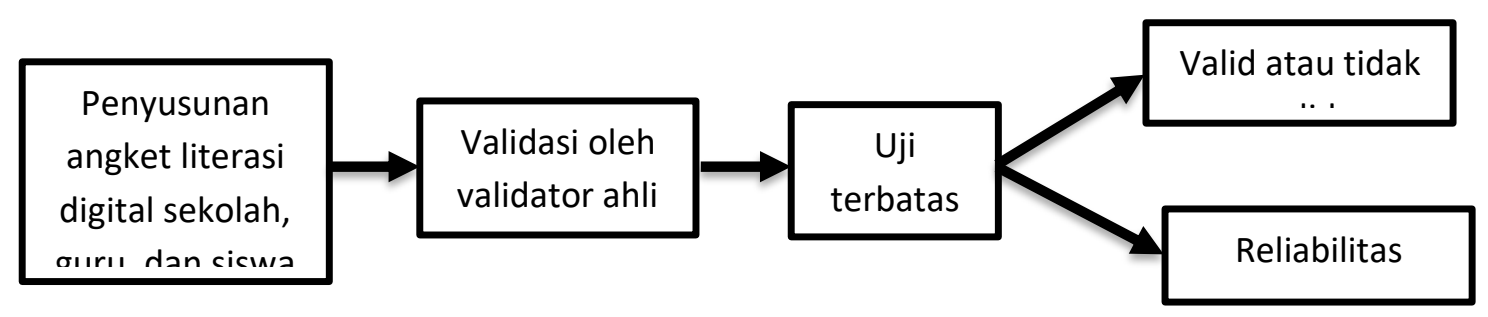

Gambar 1. Prosedur penelitian.

Angket yang telah dibuat terlebih dahulu divalidasi oleh 2 validator ahli, setelah dinyatakan valid oleh validator ahli selanjutnya angket dilakukan uji terbatas untuk menghitung tingkat validitas dan realiabilitas masing-masing item pertanyaan. Penyusunan butir pertanyaan dilakukan dengan merumuskan kisi-kisi pertanyaan dengan menggunakan skala likert dengan 3 kategori pilihan jawaban (sering, jarang, tidak pernah atau ada, sedang direncanakan, tidak, dsb). Kisi-kisi angket literasi digital sekolah mencakup 5 indikator dengan total pertanyaan sebanyak 24 butir. Adapun kisi-kisi anget literasi digital sekolah dapat dilihat pada tabel 1.

Tabel 1. Kisi-kisi angket literasi digital sekolah

\begin{tabular}{clc}
\hline No & \multicolumn{1}{c}{ Indikator } & Butir pertanyaan \\
\hline 1 & Gerakan membaca & $1,2,3,4$ \\
2 & Membudayakan e-learning & $5,6,7,8,9,10,11,12,13$ \\
3 & Membudayakan e-mail dan/atau blog sekolah/guru & $14,15,16,17$ \\
4 & Penyediaan sarana e-literasi & $18,19,20,21,22$ \\
5 & Penyediaan materi ajar elektronik & $23,24,25,26$ \\
\hline \multicolumn{2}{l}{ Total pertanyaan } & 24 item \\
\hline
\end{tabular}

Selain angket literasi digital sekolah juga dirumuskan butir-butir pertanyaan untuk angket literasi digital guru dengan 7 rumusan indikator dengan total pertanyaan sebanyak 53 butir. Rincian mengenai 
kisi-kisi angket literasi digital yang memuat indikator penyusunan butir pertanyaan disajikan pada tabel 2 .

Tabel 2. Kisi-kisi angket literasi digital guru

\begin{tabular}{|c|c|c|}
\hline No & Indikator & Butir pertanyaan \\
\hline 1 & $\begin{array}{l}\text { Pengalaman menggunakan TIK dalam } \\
\text { mengajar }\end{array}$ & 1,2 \\
\hline 2 & $\begin{array}{l}\text { Mengakses informasi dari internet dalam } \\
\text { proses belajar mengajar }\end{array}$ & $3,4,5,6$ \\
\hline 3 & $\begin{array}{l}\text { Dukungan untuk guru dalam } \\
\text { menggunakan TIK }\end{array}$ & $7,8,9,10,11,12,13,14,15,16,17$ \\
\hline 4 & $\begin{array}{l}\text { Aktifitas dan materi berbasis TIK yang } \\
\text { digunakan untuk mengajar }\end{array}$ & $18,19,20,21,22,23,24,25,26,27$ \\
\hline 5 & $\begin{array}{l}\text { Hambatan penggunaan ICT dalam } \\
\text { proses belajar mengajar }\end{array}$ & $28,29,30$ \\
\hline 6 & Skill Guru & $\begin{array}{c}31,32,33,34,35,36,37,38,39,40 \\
41,42,43,44,45,46\end{array}$ \\
\hline 7 & ICT dalam manajemen sekolah & $47,48,49,50,51,52,53$ \\
\hline \multicolumn{2}{|c|}{ Total pertanyaan } & 53 \\
\hline
\end{tabular}

Selanjutnya, angket literasi digital siswa disusun untuk mengidentifikasi literasi digital siswa secara umum yang mengacu kepada 6 indikator dengan total 30 butir pertanyaan. Secara rinci kisi-kisi angket literasi digital siswa dapat dilihat pada tabel 3.

Tabel 3. Kisi-kisi angket literasi digital siswa

\begin{tabular}{clc}
\hline No & \multicolumn{1}{c}{ Indikator } & Butir pertanyaan \\
\hline 1 & Pengguaan teknologi & $1,2,3,4,5,6$ \\
2 & Penggunaan Mobilephone/ Handphone/ & $7,8,9,10,11,12,13,14$ \\
& Smartphone & $15,16,17,18$, \\
3 & Jejaring Sosial & $19,20,21,22$ \\
4 & Pengaturan Privacy & $23,24,25,26$ \\
5 & Online safety & 27,28 \\
6 & Dampak positif teknologi & 29,30 \\
\hline \multicolumn{2}{l}{ Total pertanyaan } & 30 \\
\hline
\end{tabular}

Perhitungan validitas dan reliabilitas dilakukan dengan bantuan Ms. Excel dimana pengujian validitas diuji dengan menggunakan rumus korelasi product moment angka kasar pada persamaan (1). Perhitungan dilakukan dengan bantuan Ms.Excel dengan menghitung $\mathbf{r}_{\text {product moment }}$.

$$
r_{x y}=\frac{N \Sigma x y_{-\left(\sum x\right)}\left(\sum y\right)}{\sqrt{\left(N \Sigma x^{2}-\left(\sum x\right)^{2}\left(N \Sigma y^{2}-(\Sigma y)^{2)}\right.\right.}}
$$

Dimana:

$\mathrm{r}_{\mathrm{xy}} \quad=$ Koefisien korelasi antara variabel $\mathrm{X}$ dan variabel $\mathrm{Y}$

$\Sigma_{\mathrm{xy}} \quad=$ Jumlah perkalian antara variabel $\mathrm{x}$ dan $\mathrm{Y}$

$\Sigma \mathrm{x}_{2}=$ Jumlah dari kuadrat nilai $\mathrm{X}$

$\Sigma \mathrm{y}_{2} \quad=$ Jumlah dari kuadrat nilai $\mathrm{Y}$ 
$(\Sigma \mathrm{x})_{2}=$ Jumlah nilai $\mathrm{X}$ kemudian dikuadratkan

$(\Sigma \mathrm{y})_{2} \quad=$ Jumla nilai Y kemudian dikuadratkan

Keputusan valid tidaknya pertanyaan ditentukan dari nilai rhitung, dimana pertanyaan dinyatakan valid apabila nilai rhitung $>$ rtabel. Kategori validitas yang dikemukakan oleh (Sugiyono, 2016) terdapat pada tabel 4.

Tabel 4. Kategori validitas

\begin{tabular}{cc}
\hline Nilai & Kategori \\
\hline $0,80<\mathrm{r}_{\mathrm{xy}} \leq 1,00$ & validitas sangat tinggi (sangat baik) \\
$0,60<\mathrm{r}_{\mathrm{xy}} \leq 0,80$ & validitas tinggi (baik) \\
$0,40<\mathrm{r} \mathrm{xy} \leq 0,60$ & validitas sedang (cukup) \\
$0,20<\mathrm{r} \mathrm{xy} \leq 0,40$ & validitas rendah (kurang) \\
$0,00<\mathrm{r} x \mathrm{x} \leq 0,20$ & validitas sangat rendah (jelek) \\
$\mathrm{Rxy} \leq 0,00$ & tidak valid \\
\hline
\end{tabular}

Reliabilitas adalah tingkat ketetapan suatu instrument mengukur apa yang diukur (Febliza, A., Afdal, 2015). Pada penelitian ini perhitungan reliabilitas dilakukan dengan Teknik belah dua (split half technique) yang dilakukan dengan cara membagi dua bagian pertanyaan sama banyak yaitu dengan sistem ganjil dan genap. Koefisien reliabilitas keseluruhan dapat dihitung dengan rumus SpearmenBrown pada persamaan (2) dan pedoman kriteria tingkat reliabilitas dapat dilihat pada tabel 5 (Hadi, 2000).

$$
r_{i}=\frac{2 r_{b}}{1+r_{b}}
$$

Dimana: $\mathrm{r}_{\mathrm{i}}=$ reliabilitas instrument seluruh instrument.

$\mathrm{rb}=$ korelasi product moment antara belahan pertama dan kedua

Tabel 5. Pedoman kriteria reliabilitas

\begin{tabular}{cc}
\hline Nilai & Kategori \\
\hline $0,800-1,000$ & Sangat tinggi \\
$0,600-0,799$ & Tinggi \\
$0,400-0,599$ & Cukup \\
$0,200-0,399$ & Rendah \\
$0,000-0,199$ & Sangat rendah \\
\hline
\end{tabular}

\section{HASIL DAN PEMBAHASAN}

Data yang telah diperoleh yaitu angket literasi digital sekolah, guru dan siswa yang telah divalidasi oleh validator ahli, selanjutnya dilakukan uji terbatas untuk menghitung tinkat validitas dan reliabilitas masing-masing burtir pertanyaan. Adapun ringkasan hasil analisis data validitas angket literasi digital sekolah dapat dilihat pada Tabel 6.

Tabel 6. Ringkasan hasil analisis data validitas angket literasi digital sekolah

\begin{tabular}{ccccccr}
\hline Interval & $\begin{array}{c}\text { Kategori } \\
\text { validitas }\end{array}$ & Nomor pertanyaan & $\begin{array}{c}\text { Banyak } \\
\text { pertanyaan }\end{array}$ & & Tindak lanjut & \\
\hline $0,80<\mathrm{r}_{\mathrm{xy}} \leq 1,00$ & Sangat Tinggi & $5,6,7,8,9,10,11$, & 20 & Dapat & digunakan & sebagai \\
\hline
\end{tabular}




\begin{tabular}{|c|c|c|c|c|}
\hline & & $\begin{array}{l}12,13,14,15,16 \\
17,18,19,20,21 \\
22,23,24\end{array}$ & & $\begin{array}{l}\text { pertanyaan dalam pengumpulan } \\
\text { data }\end{array}$ \\
\hline $0,60<r_{x y} \leq 0,80$ & Tinggi & 4 & 1 & $\begin{array}{l}\text { Dapat digunakan sebaga } \\
\text { pertanyaan dalam pengumpulan } \\
\text { data }\end{array}$ \\
\hline $0,40<r_{x y} \leq 0,60$ & Sedang & 2 & 1 & $\begin{array}{l}\text { Dapat digunakan sebaga } \\
\text { pertanyaan dalam pengumpulan } \\
\text { data }\end{array}$ \\
\hline $0,20<r_{x y} \leq 0,40$ & Rendah & 3 & 1 & $\begin{array}{lrr}\text { Perlu perbaikan } & \text { sebelum } \\
\text { dijadikan sebagai } & \text { item } \\
\text { pengumpul data } & \end{array}$ \\
\hline $0,00<r_{x y} \leq 0,20$ & $\begin{array}{l}\text { Sangat } \\
\text { rendah }\end{array}$ & - & - & - \\
\hline $\mathrm{r}_{\mathrm{xy}} \leq 0,00$ & Tidak valid & 1 & 1 & $\begin{array}{l}\text { Tidak dapat dijadikan sebagai } \\
\text { item pengumpul data }\end{array}$ \\
\hline
\end{tabular}

Berdasarkan Tabel 6 mengenai ringkasan hasil analisis data validitas angket literasi digital sekolah diketahui bahwa 23 pertanyaan dapat dijadikan sebagai alat pengumpul data, meskipun ada satu pertanyaan yaitu pada pertanyaan yang ke-3 harus diperbaiki terlebih dahulu sebelum dijadikan sebagai alat pengumpul data. Sedangkan pertanyaan no 1 tidak dapat dijadikan sebagai alat pengumpul data dikarenakan tidak valid. Kelebihan dari angket literasi digital sekolah ini yaitu memiliki $83 \%$ butir pertanyaan dengan tingkat validitas yang tinggi, sehingga sudah dapat langsung digunakan untuk mengukur tingkat literasi digital. Cheng et al (2016) mengungkapkan bahwa validasi isi merupakan salah satu prosedur psikometrik yang menghitung kemampuan suatu alat tes untuk mengukur. Selain itu, bentuk pertanyaan tertutup lebih memudahkan responden dalam menjawab tanpa memberikan pendapat yang dapat mempengaruhi peneliti (Reja, Manfreda, \& Hlebec, 2003). Kelemahan angket ini yaitu validasi dari ahli tanpa menghitung content validity ratio (CVR) dari validator ahli. Ringkasan hasil analisis validitas angket literasi digital guru diuraikan pada Tabel 7, sedangkan ringkasan hasil analisis validitas angket literasi digital siswa dapat dideskripsikan pada Tabel 8.

Tabel 7. Ringkasan hasil analisis data validitas angket literasi digital guru

\begin{tabular}{|c|c|c|c|c|}
\hline Interval & $\begin{array}{l}\text { Kategori } \\
\text { validitas }\end{array}$ & Nomor pertanyaan & $\begin{array}{c}\text { Banyak } \\
\text { pertanyaan }\end{array}$ & Tindak lanjut \\
\hline $0,80<\mathrm{r}_{\mathrm{xy}} \leq 1,00$ & Sangat Tinggi & - & - & - \\
\hline $0,60<r_{x y} \leq 0,80$ & Tinggi & $\begin{array}{c}2,7,8,12,13,14 \\
17,31,32,36,37 \\
39,40,41,43,44 \\
46,47,49,50,51, \\
52,53\end{array}$ & 23 & $\begin{array}{l}\text { Dapat digunakan sebagai } \\
\text { pertanyaan dalam pengumpulan } \\
\text { data }\end{array}$ \\
\hline $0,40<\mathrm{r}_{\mathrm{xy}} \leq 0,60$ & Sedang & $\begin{array}{c}1,5,9,11,15,16, \\
18,19,20,23,24, \\
25,26,27,33,35 \\
38,42,48\end{array}$ & 19 & $\begin{array}{l}\text { Dapat digunakan sebagai } \\
\text { pertanyaan dalam pengumpulan } \\
\text { data }\end{array}$ \\
\hline $0,20<\mathrm{r}_{\mathrm{xy}} \leq 0,40$ & Rendah & $\begin{array}{c}3,4,6,10,21,22 \\
28,30,45\end{array}$ & 9 & $\begin{array}{lrr}\text { Perlu } & \text { perbaikan } & \text { sebelum } \\
\text { dijadikan } & \text { sebagai } & \text { item } \\
\text { pengumpul data } & \\
\end{array}$ \\
\hline $0,00<\mathrm{r}_{\mathrm{xy}} \leq 0,20$ & $\begin{array}{l}\text { Sangat } \\
\text { rendah }\end{array}$ & 34 & 1 & $\begin{array}{lrr}\text { Perlu perbaikan } & \text { sebelum } \\
\text { dijadikan } & \text { sebagai } & \text { item } \\
\text { pengumpul data } & \end{array}$ \\
\hline
\end{tabular}




$\begin{array}{lllll}\mathrm{r}_{\mathrm{xy}} \leq 0,00 & \text { Tidak valid } & 29 & 1 & \begin{array}{l}\text { Tidak dapat dijadikan sebagai } \\ \text { item pengumpul data }\end{array}\end{array}$

Tabel 7 menunjukkan bahwa 52 item pertanyaan dinyatakan valid, hanya saja dari 52 pertanyaan terdapat 10 pertanyaan yang memiliki tingkat validasi yang rendah dan sangat rendah. Sepuluh pertanyaan ini dapat dijadikan sebagai alat pengumpul data dengan melakukan perbaikan terlebih dahulu. Sedangkan 1 pertanyaan yang memiliki kategori validitas tidak valid, sebaiknya dihilangkan karena tidak dapat digunakan sebagai alat pengumpul data. Berdasarkan perhitungan validitas terlihat bahwa $79 \%$ butir pertanyaan dapat digunakan sebagai alat pengumpul data. Sedangkan $21 \%$ lainnya dapat digunakan dengan melakukan perbaikan terlebih dahulu.

Tabel 8. Ringkasan hasil analisis data validitas angket literasi digital siswa

\begin{tabular}{|c|c|c|c|c|}
\hline Interval & $\begin{array}{l}\text { Kategori } \\
\text { validitas }\end{array}$ & Nomor pertanyaan & $\begin{array}{c}\text { Banyak } \\
\text { pertanyaan }\end{array}$ & Tindak lanjut \\
\hline $0,80<\mathrm{r}_{\mathrm{xy}} \leq 1,00$ & Sangat Tinggi & - & - & - \\
\hline $0,60<r_{x y} \leq 0,80$ & Tinggi & $4,10,11,14$ & 4 & $\begin{array}{l}\text { Dapat digunakan sebagai } \\
\text { pertanyaan dalam pengumpulan } \\
\text { data }\end{array}$ \\
\hline $0,40<r_{x y} \leq 0,60$ & Sedang & $\begin{array}{c}1,2,3,8,9,12,13 \\
15,16,18,19,20 \\
25,27\end{array}$ & 14 & $\begin{array}{l}\text { Dapat digunakan sebagai } \\
\text { pertanyaan dalam pengumpulan } \\
\text { data }\end{array}$ \\
\hline $0,20<r_{x y} \leq 0,40$ & Rendah & $\begin{array}{c}5,6,7,17,21,22 \\
23,24,26,29\end{array}$ & 12 & $\begin{array}{lrr}\text { Perlu perbaikan } & \text { sebelum } \\
\text { dijadikan } \quad \text { sebagai } & \text { item } \\
\text { pengumpul data } & \end{array}$ \\
\hline $0,00<r_{x y} \leq 0,20$ & $\begin{array}{l}\text { Sangat } \\
\text { rendah }\end{array}$ & 30 & 1 & $\begin{array}{c}\text { Perlu perbaikan sebelum } \\
\text { dijadikan sebagai item } \\
\text { pengumpul data }\end{array}$ \\
\hline$r_{x y} \leq 0,00$ & Tidak valid & - & - & - \\
\hline
\end{tabular}

Berdasarkan Tabel 8 mengenai ringkasan hasil analisis data validitas angket literasi digital siswa terlihat bahwa seluruh pertanyaan dinyatakan valid, hanya saja ada 13 pertanyaan yang dinyatakan memiliki tingkat validitas rendah dan sangat rendah. Namun, pertanyaan ini masih dapat digunakan sebagai alat pengumpul data dengan melakukan perbaikan terlebih dahulu. Hal ini berarti terdapat $60 \%$ pertanyaan yang langsung dapat digunakan sebagai alat pengumpul data. Sedangkan 40\% lainnya dapat digunakan dengan melakukan perbaikan terlebih dahulu. Hasil perhitungan reliabilitas angket literasi digital sekolah, guru, dan siswa dapat dilihat pada Tabel 9.

Tabel 9. Hasil pengujian reliabilitas angket literasi digital sekolah, guru dan siswa

\begin{tabular}{lcc}
\hline \multicolumn{1}{c}{ Angket } & Reliabilitas & Kriteria reliabilitas \\
\hline Angket literasi digital sekolah & 0,870 & Sangat tinggi \\
Angket literasi digital guru & 0,779 & Tinggi \\
Angket literasi digital siswa & 0,684 & Tinggi \\
\hline
\end{tabular}

Berdasarkan Tabel 9 dapat terlihat bahwa angket literasi digital sekolah memiliki tingkat reliabilitas yang sangat tinggi, sedangkan angket literasi digital guru dan siswa memiliki tingkat reliabilitas yang tinggi. George \& Mallery dalam Aksoy (2016) mengungkapkan bahwa reliabilitas angket diatas 0,7 memiliki tingkat konsistensi yang dapat diterima.

\section{KESIMPULAN}


Berdasarkan hasil dan kesimpulan dapat ditarik kesimpulan bahwa angket literasi digital sekolah, guru, dan siswa dapat digunakan sebagai alat pengumpul data, dimana lebih dari $60 \%$ butir pertanyaan memiliki tingkat validitas yang tinggi dengan tingkat konsistensi yang dapat diterima.

\section{UCAPAN TERIMA KASIH}

Penulis mengucapkan terimakasih kepada DRPM Kemenristekdikti yang telah mendanai penelitian ini, sehingga penelitian ini dapat terlaksana.

\section{DAFTAR PUSTAKA}

A'yuni, Q. Q. (2015). Literasi digital remaja di kota surabaya. Libri-Net, 4(2), 1-15. Retrieved from http://journal.unair.ac.id/literasi-digital-remaja-di-kota-surabaya-article-9195-media-136category-8.html

Akbar, M. F., \& Anggaraeni, F. D. (2017). Technology in Education: Digital Literation and SelfDirected Learning in Students Students. Jurnal Indigenous, 2(1), 28-38.

Aksoy, Z.D \& Gökçe, P. (2016). Measuring Digital Literacy Skill: Development, Reliability, and Validity of Open-ended Test. International Journal of Educational Research Review, 1(1). Retrieved from https://www.ijere.com/public/frontend/uploads/submissionrevfolder/335/measuring-digitalliteracy-skill-development-reliability-and-validity-of-open-ended-test-2hdeJ.docx

Cheng, P. G. F., Ramos, R. M., Bitsch, J. A., Jonas, S. M., Ix, T., See, P. L. Q., \& Wehrle, K. (2016). sychologist in a Pocket: Lexicon Development and Content Validation of a Mobile-Based App for Depression Screening. JMIR MHealth and UHealth. https://doi.org/https://doi.org/10.2196/mhealth.5284

Febliza, A., Afdal, Z. (2015). Statistika Dasar Penelitian Pendidikan. Pekanbaru: Adefa Grafika.

Hadi, S. (2000). Statistik. Yogyakarta: Andi Offset.

Herdhita Vidya, K. (2017). Literasi Digital di kalangan Guru SMA di Kota Surabaya. Journal Universitas Airlangga, 6(4), 31-32.

Kurnia, N., Santi, D., \& Astuti, I. (2017). Peta gerakan literasi digital di indonesia: studi tentang pelaku, ragam kegiatan, kelompok sasaran dan mitra.

Nurjanah, E., Rusmana, A., \& Yanto, A. (2017). Hubungan Literasi Digital Dengan Kualitas Penggunaan $\quad$ E-Resources, 3(2), 117-140. Retrieved from file:///C:/Users/USER 1.LAB/AppData/Local/Temp/16737-40838-1-SM.pdf

Pendidikan, K., \& Jakarta, K. (2017). Materi pendukung literasi digital.

Plomp, T., dan Nieveen, N. (2010). An Introduction to Educational Design Research. Netherlands: Netzodruk SLO.

Reja, U., Manfreda, K. L., \& Hlebec, V. (2003). Open-ended vs . Close-ended Questions in Web Questionnaires.

Shopova, T. (2014). Digital Literacy of Students and Its Improvement At the. ERIES Journal, 7(2), $2-$ 3. https://doi.org/10.7160/eriesj.2014.070201.Introduction

Sugiyono. (2016). Metode Penelitian Kuantitatif, Kualitatif dan R\&D. Bandung: PT Alfabeta.

Wartomo. (2016). Prosiding temu ilmiah nasional guru (ting) viii. Prosiding Temu Ilmiah Nasional Guru, 1-9(November), 632-641.

Wilson, J. R., \& Ph, D. (2015). Rural High School Students ' Digital Literacy, 16(2). 